Universal Decimal Classification (UDC) number 614.71; 551.588

\title{
TAKING INTO ACCOUNT A NUMBER OF CLIMATIC INDICATORS IN ENVIRONMENTAL HEALTH ASSESSMENT OF AMBIENT AIR AND IN HEALTH RISK FORECASTING
}

\section{M.A. Kreymer, V.V. Turbinski}

FBSI «Novosibirsk Research Institute of Hygiene» of the Federal Service on Customers' Rights Protection and Human Well-Being Surveillance, Russian Federation, Novosibirsk, 7 Parkhomenko St., 630108

\begin{abstract}
The patterns of the influence of climate on the concentration change in the ground-level layer of ambient air were studied. It was shown that for the assessment of results of social and health-related monitoring, it is important to consider the factors affecting the sanitary parameters of air quality and the "behaviour" of air compounds: solubility, changes in the physical and chemical properties chemical reactions, and their absorption by the biosphere. For health risk modelling, the following parameters must be known: the constant circulating part, meteorological and orographic conditions of imbalance between the income and removal (run-off) of the compounds from the atmosphere. The risk arises when the combination of meteorological parameters leads to exceeding critical hazard thresholds for the compound. In the calculations of the emission limits, circulation coefficients for each ingredient emitted into the atmosphere, must be considered separately.

Key words: harmful substances in ambient air, health assessment, climatic characteristics, social and healthrelated monitoring.
\end{abstract}

For regulation of the ambient air quality using engineering, architectural and economic decisions, health standards are applied - maximum permissible concentrations for single-time and average daily exposure of harmful substances (SanPiN 2.1.6.1032-01, paragraph 2.1). To prevent the health effects of short-term increase of such concentrations and long-term exposure of the human body (SanPiN (Sanitary Regulations and Standards) 2.1.6.1032-01, paragraph 2.3), as well as for compensation of the damage caused to health (SanPiN (Sanitary Regulations and Standards) 2.1.6.1032-01, paragraph 4.2.8), the monitoring of the atmospheric processes of dispersion, accumulation of critical doses and assessment of the risk events $[1,2]$.

To improve the Safety and Health Certificates based on the monitoring results and health risk assessments, the calculations for the typical compounds were performed which are shown in the table below: particulate matters (dust), sulfur dioxide $\left(\mathrm{SO}_{2}\right)$, carbon monoxide $(\mathrm{CO})$, nitrogen dioxide $\left(\mathrm{NO}_{2}\right)$, nitric oxide $(\mathrm{NO})$, phenol $\left(\mathrm{C}_{6} \mathrm{H}_{5} \mathrm{OH}\right)$, smoke, hydrogen fluoride $(\mathrm{HF})$, ammonia $\left(\mathrm{NH}_{3}\right)$, formaldehyde $\left(\mathrm{CH}_{2} \mathrm{O}\right)$, controlled in the ambient air of Novosibirsk at 11 meteorological sites in 2008. 
Characterization of meteorological parameters and consistent health-related patterns in assessment of ambient city air pollution and risk prediction

\begin{tabular}{|c|c|c|c|c|c|c|c|c|c|c|}
\hline Parameter & Dust & $\mathrm{SO} 2$ & $\mathrm{CO}$ & NO2 & $\mathrm{NO}$ & Phenol & Smoke & $\mathrm{HF}$ & NH3 & $\mathrm{CH} 2 \mathrm{O}$ \\
\hline $\begin{array}{l}\text { Proportion of concentrations determined at the } \\
\text { levels below the detection limit ("null values"), } \\
\%\end{array}$ & 81 & 44 & 9 & 3 & 4 & 55 & 64 & 59 & 39 & 6 \\
\hline $\begin{array}{l}\text { Proportion of concentrations determined at the } \\
\text { levels of } 1 \text { Average daily maximum permissible } \\
\text { concentration and lower, } \%\end{array}$ & 85 & 98 & 95 & 10 & 35 & 65 & 96 & 79 & 76 & 6 \\
\hline $\begin{array}{l}\text { Proportion of concentrations determined at the } \\
\text { levels above } 1 \text { Average daily maximum } \\
\text { permissible concentration but below } 10 \text { Average } \\
\text { daily maximum permissible concentration, } \%\end{array}$ & 15 & 2 & 5 & 90 & 65 & 34 & 4 & 21 & 24 & 70 \\
\hline $\begin{array}{l}\text { Proportion of concentrations determined at the } \\
\text { levels of } 10 \text { or more Average daily maximum } \\
\text { permissible concentration, } \%\end{array}$ & 0 & 0 & 0 & 0,1 & 0,02 & 1,3 & 0,04 & 0,3 & 0,4 & 24 \\
\hline $\begin{array}{l}\text { Maximum registered concentration value in } \\
\text { Average daily maximum permissible } \\
\text { concentration units }\end{array}$ & 4 & 3 & 3 & 19 & 13 & 26 & 11 & 13 & 17 & 27 \\
\hline $\begin{array}{l}\text { Frequency of occurrence during the year } 2008 \\
\text { of the maximum values of } 10 \text { or more Average } \\
\text { daily maximum permissible concentrations per } \\
1000 \text { or } 10000 \text { measurements }\end{array}$ & \multicolumn{3}{|c|}{ Cannot be registered } & $1: 10000$ & $2: 10000$ & $4: 10000$ & $1: 10000$ & $1: 1000$ & $4: 10000$ & $2: 10000$ \\
\hline $\begin{array}{l}\text { Contribution of the air temperature }\left({ }^{\circ} \mathrm{C}\right) \text { in the } \\
\text { change in the compound concentration in the } \\
\text { ambient air during the year. Coefficient of } \\
\text { determination, } \%\end{array}$ & $\begin{array}{c}2,0 \\
\text { direct }\end{array}$ & $\begin{array}{c}3,7 \\
\text { reverse }\end{array}$ & $\begin{array}{c}0,6 \\
\text { direct }\end{array}$ & $\begin{array}{c}0,5 \\
\text { direct }\end{array}$ & $\begin{array}{c}0,1 \\
\text { reverse }\end{array}$ & $\begin{array}{c}0,5 \\
\text { direct }\end{array}$ & $\begin{array}{l}5,7 \\
\text { reverse }\end{array}$ & none & $\begin{array}{c}0,5 \\
\text { direct }\end{array}$ & $\begin{array}{c}1,9 \\
\text { direct }\end{array}$ \\
\hline $\begin{array}{l}\text { Contribution of the wind speed }(\mathrm{m} / \mathrm{s}) \text { in the } \\
\text { change in the compound concentration in the } \\
\text { ambient air during the year. Coefficient of } \\
\text { determination, } \%\end{array}$ & none & none & $\begin{array}{c}1,8 \\
\text { reverse }\end{array}$ & $\begin{array}{c}0,2 \\
\text { reverse }\end{array}$ & $\begin{array}{c}0,3 \\
\text { reverse }\end{array}$ & $\begin{array}{c}1,2 \\
\text { reverse }\end{array}$ & $\begin{array}{c}0,5 \\
\text { reverse }\end{array}$ & none & $\begin{array}{c}0,4 \\
\text { direct }\end{array}$ & $\begin{array}{c}0,1 \\
\text { reverse }\end{array}$ \\
\hline \multirow{3}{*}{$\begin{array}{l}\text { Multiple regression equation according to the } \\
\text { monitoring data for } 2008 \\
\mathrm{C}(\mathrm{mg} / \mathrm{m} 3)=\mathrm{K}+\mathrm{AQ} \mathrm{T}\left({ }^{\circ} \mathrm{C}\right)+\mathrm{B} \mathrm{V}_{\mathrm{q}}(\mathrm{m} / \mathrm{s}) \\
\text { (for } \mathrm{q}=7,13 \text { and } 19 \text { hours) }\end{array}$} & $\begin{array}{c}\mathrm{K} 7=0,207 \\
\mathrm{~A} 7=0,001 \\
\mathrm{~B} 7=-0,003\end{array}$ & $\begin{array}{c}\mathrm{K} 7=0,002 \\
\mathrm{~A} 7=-0,00006 \\
\mathrm{~B} 7=0,00003\end{array}$ & $\begin{array}{c}\mathrm{K} 7=1,895 \\
\mathrm{~B} 7=-0,069\end{array}$ & $\begin{array}{l}\mathrm{K} 7=0,124 \\
\mathrm{~A} 7=0,0002 \\
\mathrm{~B} 7=-0,002\end{array}$ & $\begin{array}{l}\mathrm{K} 7=0,086 \\
\mathrm{~B} 7=-0,001\end{array}$ & $\mathrm{~K} 7=0,004$ & $\begin{array}{c}\mathrm{K} 7=0,02 \\
\mathrm{~A} 7=-0,0007 \\
\mathrm{~B} 7=-0,001\end{array}$ & $\begin{array}{l}\mathrm{K} 7= \\
0,003\end{array}$ & $\mathrm{~K} 7=0,03$ & $\begin{array}{c}\mathrm{K} 7=0,02 \\
\mathrm{~A} 7=0,0001\end{array}$ \\
\hline & $\begin{array}{l}\mathrm{K} 13=0,189 \\
\mathrm{~A} 13=0,002 \\
\mathrm{~B} 13=0,003\end{array}$ & $\begin{array}{c}\mathrm{K} 13=0,002 \\
\mathrm{~A} 13=- \\
0,00006\end{array}$ & $\begin{array}{c}\mathrm{K} 13=1,747 \\
\mathrm{~A} 13=0,01 \\
\mathrm{~B} 13=-0,027\end{array}$ & $\begin{array}{l}\mathrm{K} 13=0,116 \\
\mathrm{~A} 13=0,0004\end{array}$ & $\mathrm{~K} 13=0,082$ & $\begin{array}{l}\mathrm{K} 13=1,452 \\
\mathrm{~A} 13=0,02 \\
\mathrm{~B} 13=-0,1\end{array}$ & $\begin{array}{c}\mathrm{K} 13=0,02 \\
\mathrm{~A} 13=-0,0004\end{array}$ & $\begin{array}{l}\mathrm{K} 13= \\
0,003\end{array}$ & $\begin{array}{c}\mathrm{K} 13=0,03 \\
\mathrm{~A} 13=0,0003 \\
\mathrm{~B} 13=0,001\end{array}$ & $\begin{array}{c}\mathrm{K} 13=0,02 \\
\mathrm{~A} 13= \\
0,0001 \\
\end{array}$ \\
\hline & $\begin{array}{l}\mathrm{K} 19=0,205 \\
\mathrm{~A} 19=0,001\end{array}$ & $\begin{array}{c}\mathrm{K} 19=0,002 \\
\mathrm{~A} 19=- \\
0,00005\end{array}$ & $\begin{array}{l}\mathrm{K} 19=1,911 \\
\mathrm{~B} 19=-0,047\end{array}$ & $\begin{array}{c}\mathrm{K} 19=0,122 \\
\mathrm{~A} 19=0,0003 \\
\mathrm{~B} 19=-0,001\end{array}$ & $\begin{array}{c}\mathrm{K} 19=0,087 \\
\mathrm{~B} 19=- \\
0,001\end{array}$ & $\mathrm{~K} 19=0,003$ & $\begin{array}{c}\mathrm{K} 19=0,02 \\
\mathrm{~A} 19=-0,0006 \\
\mathrm{~B} 19=-0,001\end{array}$ & $\begin{array}{l}\mathrm{K} 19= \\
0,003\end{array}$ & $\begin{array}{c}\mathrm{K} 19=0,03 \\
\mathrm{~A} 19=0,0003 \\
\mathrm{~B} 19=0,002\end{array}$ & $\begin{array}{c}\mathrm{K} 19=0,02 \\
\mathrm{~A} 19= \\
0,0001\end{array}$ \\
\hline Low boiling and melting points, ${ }^{\circ} \mathrm{C}$ & & -10 and -75 & $\begin{array}{l}-191,5 \\
-205,02\end{array}$ & $\begin{array}{c}+21,3 \\
\text { and }-11,1\end{array}$ & $\begin{array}{c}-152 \\
\text { and }-163,6\end{array}$ & $\begin{array}{c}+182 \\
\text { and }+43\end{array}$ & & $\begin{array}{c}+19,9 \\
\text { and }-87,2\end{array}$ & $\begin{array}{c}-33,3 \\
\text { and }-77,75\end{array}$ & -19 and -92 \\
\hline
\end{tabular}


Scientific and methodical approaches to risk analysis

Pollutant levels below the detection limit ("null values") make arithmetic mean of the whole sample biased. The ambient air quality indicators in populated localities for dust, $\mathrm{C}_{6} \mathrm{H}_{5} \mathrm{OH}$, smoke, $\mathrm{SO}_{2}, \mathrm{HF}$ and $\mathrm{NH}_{3}$ can be analysed as parameters with an asymmetrical distribution, i.e. up to $40 \%$ of the samples underestimate the current value. Only for CO, $\mathrm{NO}_{2}, \mathrm{NO}$ and $\mathrm{CH}_{2} \mathrm{O}$ the statistical assessment of distribution characterizes the health effects.

The arithmetic mean, set for the sanitary and hygienic purposes, may be typical only for a homogeneous sample. For the purposes of ambient air hygiene, the representative mean value can be set only for values not exceeding the standards values of the Average daily maximum permissible concentration. This determination range includes the values for dust, smoke, $\mathrm{SO}_{2}$, $\mathrm{CO}, \mathrm{HF}$, and $\mathrm{NH} 3$.

The second homogeneous sample includes the measurements indicating the exceeded the Average daily maximum permissible concentration, but not beyond the toxicological parameter of $10 \times$ Average daily maximum permissible concentrations. This determination range includes the values for $\mathrm{NO} 2, \mathrm{NO}$, and $\mathrm{CH} 2 \mathrm{O}$.

The third sample, based on threshold principles and on measurements exceeding $10 \times$ Average daily maximum permissible concentrations, may indicate non-specific clinical effects. This level of prediction of the negative effect on human health can be attributed to $\mathrm{CH} 2 \mathrm{O}$ (24\% of samples with over $10 \times$ Average daily maximum permissible concentration), C6H5OH (1.3), NH3 (0.4), HF (0.3), NO2 (0.1), smoke (0.04) and NO (0.02).

Maximum concentrations of compounds indicate a non-calculable combination of meteorological parameters, which results in such conditions in the city which impose an expressed and significant risk to human health. It was found that the greatest hazard is formed by the following compounds: $\mathrm{CH} 2 \mathrm{O}$ with the highest concentrations of about $27 \times$ Average daily maximum permissible concentration and the frequency of occurrence during the year comprising 2 cases per 10 thousand measurements; $\mathrm{C} 6 \mathrm{H} 5 \mathrm{OH}$ with the highest concentrations of about $26 \times$ Average daily maximum permissible concentration and the frequency of occurrence during the year comprising 4 cases per 10 thousand measurements; NO2 - about $19 \times$ Average daily maximum permissible concentration, 1 case per 10 thousand measurements; NH3 - about 17× Average daily maximum permissible concentration, 4 cases per 10 thousand measurements; HF - about $13 \times$ Average daily maximum permissible concentration, 1 case per 1 thousand measurements; $\mathrm{NO}$ - about $13 \times$ Average daily maximum permissible concentration, 2 cases per 10 thousand measurements; smoke - about $11 \times$ Average daily maximum permissible concentration, 1 case per 10 thousand measurements. For dust, SO2 and $\mathrm{CO}$ the maximum value registered during 2008 did not 
exceed $5 \times$ Average daily maximum permissible concentration.

According to measurements of the compounds during 2008, the contribution of the ambient air temperature and the speed of the air masses are negligible and multidirectional. The coefficient of determination for the temperature reflects its influence on the concentration and comprises: for smoke $-5.7 \%$; for $\mathrm{SO} 2-3.7 \%$, for dust $-2.0 \%$, and for $\mathrm{CH} 2 \mathrm{O}-1.9 \%$. Coefficient of determination for the wind speed in the air reflects the influence of the concentration of $\mathrm{CO}-1.8 \%$ and of $\mathrm{C} 6 \mathrm{H} 5 \mathrm{OH}-1.2 \%$.

Meteorological processes are characterized by the following extent: during the $24 \mathrm{~h}-$ with the alternation of day and night, as the four seasons - with severe temperature variations, different types of precipitation, wind direction and formation of inversions. Together, these patterns have an annual cyclicality with environmental variability and solarterrestrial relationships lasting over many years. For the assessment of daily fluctuations of compound concentrations, the multiple regression equation was calculated

$$
C\left(\mathrm{mg} / \mathrm{m}^{3}\right)=K+A_{q} T\left({ }^{\circ} \mathrm{C}\right)+B V_{q}(\mathrm{~m} / \mathrm{s}) \text { (for } q=7,13 \text { and } 19 \text { hours). }
$$

The $\mathrm{K}$ value (constant term of the equation) at the temperature and speed equal to zero, indicates the presence in the ambient air of the "constant" concentration, maintained due to natural and anthropogenic processes of income and meteorological processes of removal. The K-value, as an indicator of the average level of pollution, does not depend on a sampling time during the day for dust, $\mathrm{SO} 2$, NO, smoke, $\mathrm{HF}, \mathrm{NH} 3$, and $\mathrm{CH} 2 \mathrm{O}$. Coefficient values for the parameters of temperature and wind in the multiple regression equation reflect the processes of income and removal of compounds from the atmosphere.

An independent equation coefficient $(\mathrm{K})$ in the morning and in the evening time was 0.2 and was equal to the median, mode and the arithmetic mean of statistical distribution of dust content in the ambient air of Novosibirsk in 2008. At noon, K value decreased due to the effect of temperature (T) and wind (V) resulting from increased solar activity. In the morning the wind effect on the concentrations of dust in the ground-level layer were converse, and in the evening - multidirectional. The content of suspended substances in winter were at the level of $0.1 \mathrm{mg} / \mathrm{m}$ (mode), and in other seasons - 0.2 .

The income and removal of dust from the atmosphere does not disturbed the established pollution balance on K. Autumn is the season associated with health risk due to a sharp increase in dust concentrations up to $4 \times$ Average daily maximum permissible concentrations.

The calculated atmospheric lifetime of SO2 [3,4] is 4-5 days and, to our knowledge, the concentration of SO2 in the atmosphere of Novosibirsk is $0.002 \mathrm{mg} / \mathrm{m} 3$. Oxidation to 
sulfates by ozone or after absorption by solid or liquid aerosols leads to a decrease in concentration, and mostly after coal and oil burning - to its recovery. When predicting the risk, in addition to ecological processes, the change of the aggregate state of SO2 must be taken into account, which occurs at air temperature of $-10^{\circ} \mathrm{C}$. Thus, $\mathrm{SO} 2$ in a gaseous form leads to pollution levels ranging from 0.0 to $0.03 \mathrm{~g} / \mathrm{m} 3$ with the arithmetic mean of 0.0012 . At the atmospheric air temperature below the SO2boiling point, pollution levels are rising and are in the range of 0.0 to $0.172 \mathrm{mg} / \mathrm{m} 3$, with the arithmetic mean of 0.0036 .

The calculated atmospheric lifetime of NO, the same as NO2 [3, 4], is 5 days. Oxidation to nitrates after absorption by solid or liquid aerosols, and the photochemical reaction with hydrocarbons facilitate the removal of a compound from the atmosphere. The change of the aggregation state takes place at a temperature below the maximum registered in $2008\left(-31^{\circ} \mathrm{C}\right)$.

$\mathrm{HF}$ changes its aggregate state from gaseous to liquid at $+19.9{ }^{\circ} \mathrm{C}$ and from liquid to solid at $-87.2{ }^{\circ} \mathrm{C}$. The content of HF in the gaseous state is not described by a multiple regression equation, while the $\mathrm{HF}$ content in the ambient air in the liquid state at temperatures below $19^{\circ} \mathrm{C}$ is described by a multiple regression equation- where $\mathrm{K}$ is the only significant value equal to 0.0032 .

The calculated atmospheric lifetime of NH3 [3,4] is 7 days. The removal of NH3 occurs following the reaction with $\mathrm{SO} 2$ with the formation of (NH4)2SO4, oxidation to nitrates. The NH3 solubility in atmospheric moisture is the highest among the compounds of interest (62.9 g per $100 \mathrm{~g}$ water). NH3 changes its aggregate state from gaseous to liquid at $33,3^{\circ} \mathrm{C}$ and from liquid to solid at $-77.2^{\circ} \mathrm{C}$, which is below the minimum temperature registered in $2008\left(-31^{\circ} \mathrm{C}\right)$.

The $\mathrm{CH} 2 \mathrm{O}$ aggregate state changes from liquid to gas at $-19.9^{\circ} \mathrm{C}$ and from liquid to solid at $-92{ }^{\circ} \mathrm{C}$. The $\mathrm{CH} 2 \mathrm{O}$ content in the gaseous state is described by the multiple regression equation

$$
C_{\mathrm{CH}_{2} \mathrm{O}}=0.0218+0.00009 T \text {. }
$$

The $\mathrm{CH} 2 \mathrm{O}$ content in the liquid state is described by the multiple regression equation

$$
C_{\mathrm{CH}_{2} \mathrm{O}}=0.0224-0.0012 V \text {. }
$$

The K-value fluctuations during the day for $\mathrm{CO}, \mathrm{NO} 2$ and $\mathrm{C} 6 \mathrm{H} 5 \mathrm{OH}$ reflect the following ecological patterns.

The calculated atmospheric lifetime of $\mathrm{CO}[3,4]$ is $0.3-3$ years, which results from atmospheric circulation, as well as from soil processes and plant absorption. The proportion 
of zero samples according to concentrations of $\mathrm{CO}$ is the highest (about half of all samples) in autumn. The arithmetic means, median and mode of concentration do not exceed 1.2 $\mathrm{mg} / \mathrm{m} 3$, and the maximum detected concentrations are not higher than $5 \mathrm{mg} / \mathrm{m} 3$. In winter, the proportion of zero samples is reduced down to $36.7 \%$, in spring - to $13.2 \%$, and in summer - to $4.5 \%$. Accordingly, the arithmetic means for pollution indexes grow, but the maximum concentrations were determined only in winter. These patterns reflect the biospheric processes of absorption of carbon oxides at $\mathrm{K}$-values from 1.7 to 1.9. Among all the controlled compounds $\mathrm{CO}$ is characterized by the lowest solubility in water which is 0.00284 grams per 100 grams of water.

The calculated atmospheric lifetime of $\mathrm{NO} 2$, as well as NO [3, 4] is 5 days. Oxidation to nitrate after absorption by solid and liquid aerosols, and the photochemical reaction with hydrocarbons facilitates the removal of the compound from the atmosphere.

Up to the temperature of $-11.1{ }^{\circ} \mathrm{C}$ NO2 maintains the solid state. Its concentration in such aggregation state is described by the multiple regression equation

$$
C_{\mathrm{NO}_{2}}=0.194+0.0033 T-0.0044 \mathrm{~V} \text {. }
$$

In the temperature range from $-11.1{ }^{\circ} \mathrm{C}$ to $+20.7{ }^{\circ} \mathrm{C}$ NO2 is present in a liquid state, with the concentration described by the following equation:

$$
C_{\mathrm{NO}_{2}}=0.115+0.0008 T \text {. }
$$

In the temperature range above $+20.7^{\circ} \mathrm{C}$ it is present in a gaseous state, with the concentration described by the following equation:

$$
C_{\mathrm{NO}_{2}}=0.114+0.0018 \mathrm{~V} \text {. }
$$

Among all of the controlled compounds, NO2 is characterized by a low solubility in water $-0.00618 \mathrm{~g}$ per $100 \mathrm{~g}$ water.

$\mathrm{C} 6 \mathrm{H} 5 \mathrm{OH}$ changes its aggregate state from gaseous to liquid at $+188.7{ }^{\circ} \mathrm{C}$ and from liquid to solid at $+40.9{ }^{\circ} \mathrm{C}$. The aggregate state change occurs at the temperature which is above the highest registered in $2008\left(+36^{\circ} \mathrm{C}\right)$. Concentration fluctuations during the day can be caused by anthropogenic factors.

The solar activity changes the aggregation state of the compounds and contributes to physical and chemical reactions in the atmosphere. The income of the compounds into the atmosphere and their removal (run-off) leads to circulation of the compounds in the ambient air for some time and generation of long-term (chronic) effects on the human body. Meteorological measurements do not always reflect human sanitary living conditions. High concentrations of compounds in the ambient air cannot be determined with simple and 
accessible meteorological parameters (such as air temperature and wind speed).

For assessment of the results of social and health-related monitoring, it is important to consider the factors affecting sanitary air quality indicators and the "behaviour" of air compounds: solubility, changes in physical and chemical properties, chemical reactions, and absorption of the compounds by the biosphere.

For health risk modelling, the following parameters must be known: the constant circulating part, meteorological and orographic conditions of imbalance between the income and removal (run-off) of the compounds from the atmosphere. The risk arises from the combination of meteorological parameters that lead to exceeding the critical hazard thresholds for a compound.

For calculations of emission limits according to the OND-86 procedure, the circulation coefficients must be known for each of the compounds emitted into the atmosphere, individually.

\section{References}

1. Ocenka riska i ushherba ot klimaticheskih izmenenij, vlijajushhih na povyshenie urovnja zabolevaemosti i smertnosti v gruppah naselenija povyshennogo riska. Rospotrebnadzor MR 2.1.10.0057-12 [An assessment of risk

and damage from climatic changes influencing an increase in disease incidence and death in high-risk population groups.Methodical guidelines of the Federal Service on Customers' Rights Protection and Human Well-Being Surveillance 2.1.10.0057-12]. Moscow, 2012.48 p.

2. Vybor bazovyh pokazatelej dlja social'no-gigienicheskogo monitoringa (atmosfernyj vozduh naselennyh mest). Metodicheskie ukazanija MU 2.1.6.792-99 [The choice of basic indicators for social and hygiene monitoring (ambient air in populated areas). Methodical guidelines MU 2.1.6.792-99]. Utverzhdeny Glavnym gosudarstvennym sanitarnym vrachom RF 19 nojabrja 1999 g. Available at: http://www.eko-partner.ru/actual_legislation/35.

3. Himija nizhnej atmosfery [Chemistry of the lower atmosphere]. Moscow: Mir, 1976, pp. $156-157$.

4. Junge H. Himicheskij sostav i radioaktivnost' atmosfery [The chemical content and radioactivity of the atmosphere]. Moscow: Mir, 1965, p. 15. 